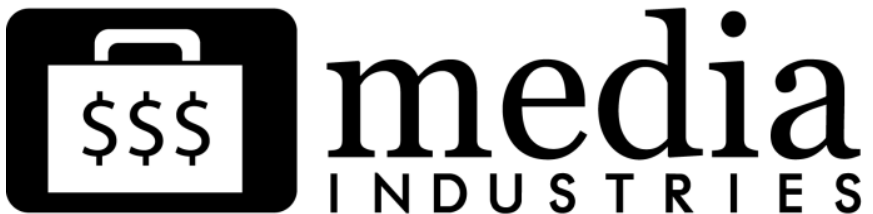

\section{Reconsidering Media Economics: From Orthodoxies to Heterodoxies}

\author{
Stuart Cunningham and Terry Flew ${ }^{1}$ \\ Queensland University of Technology \\ s.cunningham [AT] qut.edu.au \\ t.flew [AT] qut.edu.au
}

\begin{abstract}
:
This paper argues the case for closer attention to media economics on the part of media, communications, and cultural studies researchers. It points to a plurality of approaches to media economics, including the mainstream neoclassical school and critical political economy, but also new insights derived from perspectives that are less well known outside of the economics discipline, such as new institutional economics and evolutionary economics. It applies these frameworks to current debates about the future of public service media, noting limitations to both "market failure" and citizenship discourses and identifying challenges relating to institutional governance, public policy, and innovation as public service media worldwide adapt to a digitally convergent media environment.
\end{abstract}

Keywords: Media Economics, Political Economy, Institutional Economics, Evolutionary Economics, Public Service Media

There are two main standpoints that dominate our understanding of media economics and which contend for overall legitimacy in the field: neoclassical, or mainstream, media economics and critical political economy of the media. These two variants deserve to be treated as the reigning orthodoxies because they produce powerful analyses of the way media work. But they are in many ways so divergent in terms of their objects of analysis, their methodologies, and their founding assumptions that a conscientious student coming at the topic from the disciplines of media, communication, or cultural studies may find that such a divergence makes it difficult to come to grips with media economics. Scholars in the field can draw on elements from both approaches, such that some advanced research in media economics sits on a continuum between them. However, a continuing divide remains, particularly in the literature intended for a nonspecialist and student readership. In this article, we seek to work across, and beyond, the divide.

The divide between critical political economy and what we now know as neoclassical economics can be traced as far back to the different paths followed from the 1850s onward, between the "marginal revolution," on the one hand, and the work of Karl Marx and the 
socialist economists, on the other. But economics as a field is far more complex than this dualism captures. The rise of Keynesian macroeconomics in the wake of the 1930s Great Depression introduced a method that "wished to save the essentials of the capitalist system but realized that this could only be done within the framework of a strong and systematically interventionist state." 2 A series of approaches associated with reformist perspectives in political economy, including post-Keynesian economics, are very active today, as are challenges to the hegemony of neoclassical theory from the perspectives of behavioral economics, innovation economics, and "new institutionalism."

Understanding media through the prism of media economics requires that we broaden the scope of approaches that are considered, as new developments in media industries and markets are stretching the capacity of the established neoclassical and critical political economy paradigms. The new dynamics of media production and consumption involve such developments as the generalization of convergent digital media platforms across all media; the growing interest in the socioeconomic value of networks; the disruptive implications of digital media technologies on long-established media business models; the rise of user-generated media content through YouTube and other social platforms, as well as the need to reconceptualize the nature of media audiences; and the growth of creative industries' policies and programs, with their focus on media and cultural sectors as sources of wealth creation and economic innovation.

It is our contention that there are schools in the rich and deep history and contemporary practice of economics that have rarely been applied to the media but which may help us in dealing with the new developments in the media today. In this article, we compare the two dominant schools with institutional economics and evolutionary economics - strands in what the discipline calls heterodox economics - as alternatives to mainstream neoclassicism and critical political economy. ${ }^{3}$ Then, to show the value of broadening the economic frames through which to understand media, we apply these four approaches to the future of public service broadcasting (PSB) in an extended case study.

\section{Mainstream Media Economics}

The field of media economics has existed in some form since the 1950s. ${ }^{4}$ While economics has not been as central to the study of the media as communication studies, sociology, and cultural studies have, it has always had great significance beyond academia, partly due to the manner in which it aims to capture how the media works from the perspective of those who run media businesses and make media policies. Gillian Doyle makes the point that "economics, as a discipline, is highly relevant to understanding how media firms and industries operate . . . [because] most of the decisions taken by those who run media organizations are, to a greater or lesser extent, influenced by resource and financial issues." 5 Entman and Wildman make the observation that media policy research "seem[ed] to divide roughly between . . . the 'market economics' and 'social value' schools of thought," and that the "market economics" approach had a core assumption "that communications policy issues can be analyzed most fruitfully as problems in maximizing economic efficiency ... [and] that economic efficiency would promote other desirable goals." 6

Media economics has drawn upon neoclassical microeconomics, adopting its various foundational assumptions such as a focus on the individual as the primary object of analysis; the assumption that individuals engage in rational behavior in order to maximize their benefits from market transactions; the expectation that markets will reach an optimal price, or an 
equilibrium point; and the assumption that this equilibrium point will be one that maximizes benefits to both producers and consumers as a consequence of engaging in free exchange. Media markets sometimes work in this classical fashion.

But the dominance of neoclassical approaches has long had its critics. Steven Wildman, who was chief economist with the United States Federal Communications Commission from 2012 to 2014, has made the point that while neoclassical economics is still "the source of the intuition guiding much, if not most, of today's economic research," it is also the case that "the neoclassical approach ... [is] no longer the overwhelmingly dominant paradigm it once was." 7 Pieter Ballon has argued that "while the typical static efficiency analysis and its extensions of neoclassical economics can have their application in the media . . . an economic approach to the media [also] needs to be informed by information economics, and network economics, institutional economics, and evolutionary or innovation economics." 8

To some extent, such criticisms are reflective of distinctive features of the media that render it complex from the neoclassical perspective. These include:

- the heterogeneous nature of media products, and the difficulties in determining the price when there are such divergent forms of content that are being consumed;

- the dual nature of media markets, where commercial media producers and distributors seek to simultaneously offer their product to consumers and advertisers;

- tendencies toward concentration of media ownership, and the relationship between oligopolistic market structures and the capacity of incumbent media interests to influence the policy process;

- the importance of noneconomic principles in media policy, such as the promotion of diversity and media pluralism, the provision of public goods, and the sociocultural dimensions of media content;

Mainstream media economics has also been subject to various critiques from communications, media, and cultural studies researchers, who typically discount its ability to provide insights into the operations of media industries. For critical political economists such as Wasko, Murdock, and Sousa, ${ }^{9}$ media economics "avoids political and historical analysis . . . [and] mostly accepts the status quo." Such critiques echo criticisms of mainstream neoclassical economics that have been made by other economists. In the wake of the 2008 global financial crisis, Joseph Stiglitz observed that "economists had moved ... from being a scientific discipline into becoming free market capitalism's biggest cheerleader," 10 while John Quiggin attacked what he termed the "zombie ideas" that continued to influence economic policy. ${ }^{11}$ But it is important to be aware that mainstream media economics does not simply point toward promarket positions and demands for deregulation. Concerns about ownership concentration, the promotion of diversity and media pluralism, the positive externalities associated with promoting national culture through media content, and the public-good aspects of public service media are all areas where the tools of neoclassical economic theory can be deployed toward reformist media policy goals. ${ }^{12}$

\section{Critical Political Economy}

The critical political economy approach to media is the best known in the field of media, communication, and cultural studies. This is a diverse and dynamic field, albeit one with some core propositions around: the importance of understanding historical processes of social 
change; a sense of the mutually constitutive relationship between economic, social, and cultural institutions, relations, and practices; a moral philosophy oriented toward critiquing the industrial structures and social relations of capitalism; and a commitment to linking intellectual work with progressive social movements. ${ }^{13}$

With the desire for inclusiveness of diverse research paradigms within the political economy "tent," there is a tension in the field. Winseck ${ }^{14}$ identifies institutional and evolutionary economics, as well as elements of neoclassical economics, as being broadly cognate with political economy. A contrary view among leading practitioners is that critical political economy is defined in opposition to other research traditions, including creative industries approaches and media production studies. ${ }^{15}$ One site through which such debates have been-at times acrimoniously - played out is around audience studies, between the "active audience" strands of cultural studies and the critiques of such accounts as "cultural populism."

The political economy framework was the subject of extensive review and critique from within media, communication, and cultural studies over some decades, with crude base-superstructure models giving way to much more nuanced accounts of human agency, textual and audience/user productivity, and the institutional study of production, distribution, and exhibition. The foundational debates conducted between cultural studies and political economy in the 1970s and 1980s argued that political economy neglected the role of agency while stressing structural determinants in the time-honored structure-agency dialectic in the social sciences. These negotiated responses to critical political economy have been heartland concerns for cultural and media studies on and off for decades, and they continue into the present with, for example, production studies.

But these heartland debates in media, communications, and cultural studies have done little to conceptually advance what form of media economics should supplement or contend with critical political economy. In the absence of extended debate about the types of economics appropriate to the contemporary media, a fairly stale recycling of the neoclassical-critical political economy debate stands in for intellectual advancement in the field. We argue that a key to understanding the strengths and limits of critical political economy is through questions concerning power, and particularly the relationship between economic, political, and symbolic or cultural power.

At its core, political economy assumes that power emanates from the ability to control the means of production and accumulation and flows from the top echelons of society to the bottom. It also posits stronger versions of the alignment of, or homology between, economic, political and symbolic/cultural power, assuming that economic power results in the ability to exercise political and symbolic/cultural power. But the ways in which powerful economic actors may also exercise political power, symbolic/cultural power, or both cannot be decided in advance, as there is no universal template or prescription for how such alignment can be achieved. Further, the concept of power, as deployed in critical political economy of the media, is what Michel Foucault ${ }^{16}$ would call domination. Foucault defines power more generally, with domination as a subset. When it comes to industries that inherently combine economic power with political and symbolic/cultural influence, like the media, we tend to side with Foucault's understanding that power is inherently relational, contingent, unstable, and reversible, and that resistance is a necessary corollary of such power.

Very large companies-particularly multinationals, that operate in oligopolistic markets, generate news and current affairs as well as entertainment, and have clear strategic intent- 
have the capacity to align economic with political power. It is clear that, in the case of a Rupert Murdoch, for example, economic power, and his unusually strong corporate position that enables him to wield it, is used to create untoward political influence across a broad spectrum of nations and issues. Other very large, well-established multinationals such as Disney operate principally to align economic with cultural power, and tend to focus their exercise of political power to single issues, such as copyright. On the matter of economic power as such, critical political economy's resolute focus on big business skews the question of power radically toward Foucault's notion of domination. The vast majority of media firms and agents are not big businesses. A political economy of small media enterprise would focus on its economic subaltern status, and would use a relational notion of power to understand its strategies.

\section{The New Institutional Economics}

Institutional approaches have a long history in the social sciences, although their status in the history of economic thought is contested. Early institutionalist economics was strongly framed by its critique of neoclassical economics, particularly the assumption that "the self-governing individual constituted the ultimate unit of the social sciences, and that all social phenomena resolve themselves into decisions and actions of individuals." 17 In the institutionalist tradition founded by the late nineteenth-century American economist Thorstein Veblen, such methodological individualism and rational choice assumptions were seen as losing sight of the formative influence of history and culture, as given concrete form through institutions, upon the behaviors and preferences of individuals. An important bridge between this "old" institutionalism and communications theory is found in the Canadian communications tradition, with Harold Innis's analysis of the ways in which media technologies structure relations of power and patterns of social interaction, including the social shaping of markets and economic institutions. ${ }^{18}$

The new institutional economics (NIE) has emerged in part out of a recognition that the bracketing-off of economics from other academic disciplines and fields of research has come at some cost to economics. The Nobel Prize winner Douglass North ${ }^{19}$ observed that economics had cut itself off from history, neglecting the historically evolving role of institutions and the significance of how such institutions develop over time. At the same time, and in contrast to the "old" institutional economics, the NIE approach has stressed its continuities with mainstream microeconomics, particularly in retaining the architecture of rational choice theory in its analyses of individual behavior: Oliver Williamson ${ }^{20}$ argued that NIE was "for the most part ... complementary to, rather than a substitute for, conventional analysis."

The NIE has focused upon two "real-world" limitations of neoclassical economics that pointed to the need for new approaches to understanding the economics of institutions: bounded rationality and transaction costs. Bounded rationality refers to the proposition that, while individual behavior can be intentionally rational, "in practice . . . all decision makers, entrepreneurs, consumers, politicians, etc., act subject to imperfect information and limited cognition." 21 Transaction costs are the costs of running the economic system; they include market engagement costs, managerial transaction costs-particularly those involving employment contracts within firms - and political transaction costs, or the costs of maintaining political and legal institutions associated with the running of a polity and governing a political system.

A particularly important group of transactions are those characterized by asset specificity, where both the nature of the asset and its use are incompletely defined. An example is the 
hiring of skilled workers sought for particular roles that have attributes unique to that person, and where the role has been structured with an expectation that the particular individual can define the tasks involved. Richard Caves ${ }^{22}$ observed that the media and creative industries are rife with hiring practices that draw upon a-frequently intangible-concept of asset specificity, or what he termed the "A list/B list" phenomenon, where creative workers are frequently engaged in implicit contracting with their employers, with salaries contingent upon achieving particular performance outcomes (program ratings, music downloads, box office success, etc.). "Reputation" constitutes a performance metric that is highly resistant to standards and measurement, but that becomes decisive in one's ability to secure ongoing work in the media industries.

The assumptions of bounded rationality and positive transaction costs led NIE theorists to understand the firm not simply as the institutional site through which goods are produced but as a nexus of contracts. Drawing on insights originally developed by Ronald Coase, ${ }^{23}$ the firm is seen as economizing on transaction costs through vertical integration of activities across the supply chain, and by generating single, incomplete employment contracts. Such incomplete contracts reduce the costs of conducting multiple formal transactions with all employees but are by their very nature premised upon the idea that such contracts exist within a wider structure of embedded social and interpersonal relations.

NIE defines institutions as "the humanly devised constraints that structure human interaction" 24 and understands them in two senses. First, there are institutional arrangements or governance structures through which resources are allocated within particular organizations (microscopic level); this is the level of the firm or organization, as discussed above. Second, there is the institutional environment (macroscopic level): the "rules of the game in a society, or ... the humanly devised constraints that shape human interaction." 25 Within the institutional environment, a further distinction is made between formal institutions, which include rules, laws, constitutions, allocations of property rights, and so forth, and informal constraints, such as norms of behavior, conventions, and self-imposed codes of conduct. ${ }^{26}$ While both form the "rules of the game" through which particular forms of action are either encouraged (through incentives) or discouraged (through laws, constraints, and punishments), formal institutions are more amenable to substantive change - through concerted political action, for example - than to the more historically and culturally embedded informal constraints.

\section{Evolutionary Economics}

It has been a fundamental charge from the heterodox schools against neoclassical, or equilibrium, economics that it is not well equipped to account for change and growth. Whereas mainstream economics emphasizes equilibrium, choice under conditions of scarcity, and rational, utility-maximizing agents, evolutionary economics stresses nonequilibrium processes that transform economies, firms, institutions, industries, and employment from within. It treats processes of technological and institutional change and innovation not as exogenous shocks to an internally equilibrating system but as endogenous to economies. ${ }^{27}$ Such endemic change arises from the ceaseless activity of diverse agents with bounded rationality (a model of human behavior much closer to observable reality than the neoclassical model of the "utilitymaximizing" individual).

Evolutionary economics offers a substantive alternative to neo-Marxist political economy and is based on a model of the effects, bad and good, of living under capitalism that is dynamic, conflict-driven, and explicitly indebted to Marxism. ${ }^{28}$ This model is carried in the phrase creative 
destruction, "a term originally derived from Marxist economic theory which refers to the linked processes of the accumulation and annihilation of wealth under capitalism." 29 The idea is powerful because it insists that "accumulation" (economic development, the greater good for the greater number, etc.) and "annihilation" (business failure, environmental degradation, etc.) are mutually constitutive forces. The term creative destruction has become virtually synonymous with the work of Austrian-American economist Joseph Schumpeter since his major prognostications on the future of Capitalism, Socialism, and Democracy. ${ }^{30}$

Schumpeter emphasized that such change can be triggered by entrepreneurial effort allied with technological disruption, which keeps the capitalist "engine" in perpetual disequilibrium, destroying established value and creating new value. Schumpeter's economics fell into obscurity during the long boom of Western postwar industrial growth and Keynesian social redistribution, but his approach came back into prominence as the world searched for new models of growth in the wake of the 1970s oil shocks, stagflation, and the decline of the Keynesian settlement. Innovation and entrepreneurialism increasingly became watchwords for postindustrial economies, and Schumpeter's "second coming" has underpinned the development of contemporary innovation economics, which draws strongly on both institutional and evolutionary inputs. ${ }^{31}$ Contemporary evolutionary economics studies growth and change in economic systems under conditions of variety generation, enterprise competition and selection, and self-organization. ${ }^{32}$

The core advance that this approach might facilitate is to understand the rates and significance of digital disruption in contemporary media economies, 33 and digital media as an emergent, enabling technology across the broader services sector of the economy. Schumpeter allied his notion of business cycles to Kondratieff's long-wave cycles, of which there have been five since the Industrial Revolution, moving through (1) steam and cotton, (2) steel and railways, (3) chemistry and electrical engineering, (4) petrochemicals and cars, and (5) information and communications technologies. Contemporary analysts ${ }^{34}$ have proposed an expansion of the fifth or a new, sixth, wave consisting of biotech, pharmaceuticals, alternative energy, software, mobile communications, and digital technology. This provides us with a deep historical context within which to place the significance of digital media and the way in which new technologies are integrated into an economy and the restructuring of organizations, industries, markets, and consumer lifestyles that the evolutionary process engenders.

\section{Public Service Media}

We now apply these four approaches to the role and performance of public service broadcasters (PSBs), or, as they are increasingly being termed in an era of multiplatform media and convergence, public service media (PSM), exploring familiar and fresh arguments for and against publicly funded media. NIE provides analytical tools that identify issues pertaining to PSM such as the challenges of organizational complexity, the complex governance structures of PSM organizations, and how best to ensure that their decisions are in the public interest. A case can be made for the continuing importance of PSM in a convergent media environment through evolutionary economics, as it identifies such organizations as important sites of new media innovation, with a policy remit and governance framework that enables them to undertake research and development in the public interest that is demonstrably different to the priorities of commercial media corporations. 


\section{Neoclassical Economics and PSBs: Market Failure}

The mainstream economic case for public service broadcasting (PSB) has revolved around the concept of market failure, with particular reference to public goods, externalities, and merit goods. While the spectrum scarcity rationale for PSB clearly does not apply in a convergent media environment, over-the-air broadcasting is still seen as having the characteristics of a public good in that it is nonexcludable (freely available to everyone who owns necessary reception equipment) and nonexhaustible (there are zero marginal costs involved in providing the service to each additional viewer). ${ }^{35}$ Moreover, PSBs have been considered a suitable means of generating programming that has merit (quality programming, programming of national political or cultural significance, programs aimed at minority communities or interests, educational programming, etc.), as they are not beholden to shareholders to make a profit-nor are they obligated to maximize advertiser revenues or audience share across the programming schedule.

The question of how significant market failure arguments for PSB are in an era of digital technologies and multichannel broadcasting remains a subject of contention. Armstrong ${ }^{36}$ has argued that digital-subscription broadcasting has significantly weakened market failure rationales for PSB by enabling a wider range of niche channels to be available in fields such as the arts, history, and science and allowing consumers to more directly determine the menu of program choices available to them. It is also the case that quality television can no longer be deemed to exclusively come from PSBs, if indeed it ever could. In the United States, where PSB is marginal and the market is by far the largest in the world, the turn to high-concept, edgy, and innovative dramas was led by the premium cable network Home Box Office (HBO), followed by other cable networks, such as AMC.

In responding to the challenges of content proliferation and quality niche programming, authors such as Gavyn Davies ${ }^{37}$ have argued that niche services are not universally available, and that there continue to be deficiencies in the supply of informational or educative content that may have merit good attributes, even in a multichannel environment. Religious programming is a case in point. Cable services are often awash with channels of various faithbased groups, and there could be little complaint about a lack of access to religious content. But the PSB remit in this area is quite different: it is not necessarily providing content to believers in various religious faiths but rather critical reflection on religion and its role in society. Faithbased PSB is meant to enable greater lay understanding of various religious faiths and their relationship to one another rather than to promote any particular faith, church, or denomination. In that respect, then, there continues to be a "market failure" in religious programming that arguably only PSBs can adequately address.

At the same time, ubiquitous access to the internet further complicates the market failure arguments for PSB. For example, if one case for PSB was its ability to cater for cultural and linguistic minorities, it is apparent that such groups now have greatly enhanced access to content in their own languages, or from their homeland communities. Similar points could be made about news and information content, or almost any particular media content area. Media convergence also raises new questions about the involvement of PSBs in the digital environment, or the transition from public service broadcasting to multiplatform PSM. In what ways do the charters of PSBs need to be modified in this new environment? What does the case for market failure look like if one removes the prior rationale of spectrum scarcity as a barrier to entry for new players? 
What we find is that debates about whether public service media is warranted on the basis of market failure draw attention to the degree to which neoclassical economics presents us with models decontextualized from questions of culture and history. PSBs have evolved worldwide in a variety of ways, and the path-dependent evolution of such institutions in national media systems is poorly explained by using the blanket "market-failure" rationales. While market failure provides one normative basis for making claims about PSBs in general, it has significant weaknesses in providing a basis for evaluating the structure, conduct, and performance of PSBs in practice.

\section{Critical Political Economy and PSBs: Media Citizenship}

The approach of critical political economists toward PSBs has varied over time. Early accounts 38 developed a class-based critique of what they saw as an elitist bias in broadcasters such as the British Broadcasting Corporation (BBC), as well as those outlets' downplaying of social divisions based upon class. In more recent work, however, this critical and class-based perspective has been displaced by a more normative account that presents PSBs as central to nation building, and to furthering the values of citizenship against the commoditized products of the commercial market. To take one recent example, Murdock ${ }^{39}$ has argued that public service media are rooted in a "moral economy" of the collective public good, inherently aligned with other public cultural institutions such as public libraries, parks, museums, and galleries that are part of the entitlements of democratic citizenship and resources for enhancing the quality of communal life.

In considering these arguments for public service media, an issue that arises is what constitutes a PSB, as this is less straightforward than it first appears. Noncommercialism is a difficult distinction to sustain, partly because many PSBs worldwide-possibly the majority-carry commercial advertising. There are also elements of similarity in the incentive structures that exist within PSBs and commercial media. Even those PSBs that do not carry commercial advertising, such as the BBC or Australia's ABC, are nonetheless engaged in major "ancillary" commercial operations. Public ownership is also not in itself a sufficient criterion for PSB status. The world's largest publicly owned broadcaster is now China Central Television (CCTV). The fraught overlap between state and public broadcasting, particularly in transitional (postsocialist) and expanding East Asian systems has often been absent from most accounts of the future of PSBs.

The definition of PSBs, then, has been as much normative as it has been institutional, constructed around their relationship to discourses of citizenship and the public sphere. What we find is a gap between the normative dimension of PSBs and what they do in practice, or what Collins referred to as the divide between the "ises" and the "oughts" of PSB. ${ }^{40}$ PSBs clearly provide a range of popular programs, whose appeal is measured by the same indicators as those used by commercial media, such as ratings and other audience-measurement techniques. This is a manifestation of the practical tension between PSB charters, which give them a particular role in providing quality programming and "leading ... public and popular taste," and the political reality that "their social productivity (and institutional legitimacy) depends on the degree to which their programs and services are used and valued by listeners and viewers." 41

It has also been noted that features commonly identified as being central to the public service mission-quality and innovative programs, providing a public space of information and debate, catering to national identity and community, catering for minority tastes, interests, and so 
forth - can also be provided by commercial media. We noted that premium cable services such as HBO are clearly involved in the production of quality drama, and it is also notable that twenty-four-hour news services are provided by both PSBs and by commercial providers through dedicated subscription channels.

\section{New Institutional Economics and PSM}

In contrast to the accounts of public service media in neoclassical economics and critical political economy, which both emphasize the differences between PSM and commercial media, NIE provides us with insights into how and why PSM organizations possess similarities to their counterparts in the commercial sector. It also draws attention to particular governance challenges in ensuring the responsiveness of PSM organizations both to their charter obligations and to the publics they serve. As PSM organizations now operate within a far more complex ecology of convergent media than was the case with limited-channel broadcasting, we believe there is a need to develop more practical and applied understandings of how PSM can flourish and better serve the public good in changing institutional environments.

The NIE proposition of the firm as a "nexus of contracts" applies equally to public and private entities and for the same reasons. Large firms in both the public and private sectors have to deal with the separation of asset ownership from everyday management, and with the resulting principal-agent problems. In particular, an endemic risk is that of managers acting in ways that maximize their own returns rather than those of the assets' "owners" (shareholders, governments, or taxpayers). Increasing size reduces market uncertainty and bargaining costs but-by making the organizations larger and more diffuse-runs the risk of increasing the complexity of management tasks and becoming increasingly bureaucratic in their operations. Relational, or incentive-based, contracts are an important feature of large firms, as successful performance of work tasks is seen as dependent on the talents and motivation of particular individuals.

All of these issues arise in the media industries, where large public- and private-sector organizations deal with complex production processes, time-dependent media/creative products, and endemic uncertainty of demand. ${ }^{42}$ There is also now considerable movement of personnel between the public and private sectors, particularly as the pressures for PSM to become more corporatized see greater recruitment of managers from the commercial media sector. There are strong commonalities of view among public- and private-sector media managers around the desirability of corporate expansion, driven in part by the value attached to economies of scale and scope, the need to maximize market reach and audience share, the perceived power of media brands and, more recently, by the perceived need to be operating across multiple platforms in an era of digital convergence. There are also considerable commonalities in internal governance structures, particularly as incentive-based contracts for "star" talent have replaced public service conditions of employment across PSM organizations.

A very important and continuing point of difference between public and private media organizations concerns their ownership and governance structures. In the case of companies that are publicly listed on the share market, evidence of management underperformance can lead to a fall in shares' market price, a hostile takeover bid, or other responsive action by the owners of the company. At least in theory, financial markets are meant to provide one countervailing source of power to management power. The equivalent countervailing power for PSM is governments, which, as the notional "owners" of PSM assets, can act to deal with poorly performing management. But this raises a major problem, as such actions will invariably be 
seen as being politically motivated, not least because those subject to such decisions have strong incentives to portray themselves as political victims. Moreover, as PSM have a mix of primarily noncommercial, charter-based objectives and market-based measures such as audience share, benchmarking what is adequate performance can be difficult.

In attempting to devise a framework that can allow governments as the principal funders of PSM to address principal-agent problems and set limits on managerial autonomy, a difficulty arises in the insistence that PSM organizations must not be subject to forms of government interference, or to forms of external regulation to which other media entities are subject. For example, regulation of the $\mathrm{BBC}$ by Ofcom is considered to be inappropriate, as the editorial independence and institutional autonomy of the BBC is guaranteed by its charter, and its accountability must be to Parliament in terms that relate to its underlying legislation, not to the government of the day. While this guarantee of independence is important in its own right, one consequence is that PSM organizations can be seen to be effectively regulating themselves, which generates considerable moral hazard.

The BBC sought to address this issue in its 2006 charter review with the establishment of the BBC Trust. The trust, which commenced operations in 2007, is intended to be the governing body of the BBC, and to be operationally independent of BBC management and external bodies. Its stated aim is to "make decisions in the best interests of license fee payers." 43 The trust has been described as "a difficult, arguably cracked creation," 44 and its chair from 2011 to 2014, Chris Patton, resigned after struggling to deal with the fallout from the Jimmy Savile pedophilia revelations. Whether the BBC Trust model resolves the dilemma of PSM governance remains unproved, as the trustees arguably have to navigate the same challenges as the CEO and managing director, in dealing with the competing expectations of governments as funders, the organization's workforce, and the diverse publics it is intended to serve.

\section{Evolutionary/Innovation Economics Put to the "Public Value" Test}

The contemporary challenge to PSB to justify its position in a rapidly expanding and commercializing media ecology can be traced from the mid-1980s and the Peacock Committee on the Financing of the BBC. Appointed by Prime Minister Margaret Thatcher, who had made known her view that the BBC should be funded through advertising, Alan Peacock undertook a skeptical and highly influential review of the foundations of PSB, rejecting Thatcher's option but recommending that, over time, the universal license fee should be replaced by an opt-in subscription model as the multichannel mediascape matured and that the objectives of PSB could also be delivered through contestable funding available to a wider range of providers. ${ }^{45}$

Fast-forward to the present, and one way in which governments have sought in recent years to stress-test the role of PSM has been through the application of "public-value tests" to the development of new services. ${ }^{46}$ Such tests proposed an operational understanding of public value, whereby strategies could be assessed in terms of: (1) their contribution to outcomes deemed valuable by the community and the government as their elected representatives; (2) their sustainability in terms of gaining ongoing support from key political and other stakeholders; and (3) their feasibility in terms of the funding, technology, staff skills, and organizational capabilities needed to deliver the required public-value outcomes. The BBC adopted the concept of public value with its "Building Public Value" report, released in 2004 in advance of its charter renewal in 2005.47 It began to apply public-value tests to the introduction of new digital services in 2007.48 The concept of public value came to be increasingly important in Europe over the 2000s, as the result of European Commission policies that gave quite 
different interpretations to public service broadcasting and online extensions of the public service remit.

The European Commission has identified public service broadcasting as being central to European media pluralism, and that its contribution needs to be safeguarded in the member states. However, in the 2009 Communication on State Aid, the commission took a strong view that extension of PSB activity into the online environment was only warranted where a demonstrable market failure case existed, and where the new service clearly "added value" in relation to the "democratic, social, and cultural needs" deemed central to the public service remit. ${ }^{49}$ The need to demonstrate "distinctiveness" from the market, to show "added public value" compared to commercial offers, and to provide "predictability" for commercial competitors - the so-called "triple test" of public value-has been accompanied by what is known as the ex ante test, or the need to demonstrate all of these aspects of the new service in advance of its being launched. 50

We would argue that public-value tests are more than simply a "fad" 51 but rather constitute one attempt to develop a performance metric for PSM that makes use of public funds and has complex and sometimes conflicting organizational objectives. We can identify its roots in the neoclassical conception of market failure, and the stricture that investment in PSM is a form of government intervention in otherwise well-functioning commercial markets that can only be warranted where such market failures can be demonstrated through an ex ante public-value test.

From the perspective of evolutionary/innovation economics, however, a major flaw with these tests is that they presume that the new media markets are relatively stable, and that one can readily identify the private sector initiatives that would be "crowded out" by the entry of PSM development of new digital and online services. Cunningham ${ }^{52}$ has argued that PSM have been increasingly engaged in a "facilitative role of performing experimental R\&D for the system," while Martin and Lowe argue that by extending their offerings into online environments, PSM are "engaged in a logical, principled and appropriate adaptation to a changing media marketplace, to the evidenced interests of diverse publics." 53

So while PSB may have been associated with genre innovation in the context of universal access to its radio and TV services, PSM are increasingly presenting the case for continued public subvention on the basis of promoting digital innovation to meet contemporary expectations of public value. In this respect, then, evolutionary economics provides a different case for public service media than the more traditional-and increasingly contested-market-failure arguments of neoclassical economics and the citizenship discourses of critical political economy.

${ }^{1}$ Stuart Cunningham is Distinguished Professor of Media and Communications, Queensland University of Technology. His recent books include Hidden Innovation: Policy, Industry, and the Creative Sector (2014), Screen Distribution and the New King Kongs of the Online World (with Jon Silver, 2013), The Media and Communications in Australia (edited with Sue Turnbull, 2014) and Media Economics (with Terry Flew and Adam Swift, 2015). Terry Flew is Professor of Media and Communications, Queensland University of Technology. His recent books include The Creative Industries: Culture, and Policy (2012), Global Creative Industries (2013), New Media: An Introduction (2014), and Media Economics (with Stuart Cunningham and Adam Swift, 2015).

2 Eric J. Hobsbawm, Industry and Empire (Harmondsworth: Penguin, 1979), 245. 
3 Peter E. Earl and Ti-Ching Peng, "Brands of Economics and the Trojan Horse of Pluralism," Review of Political Economy 24, no. 3 (2012): 451-67.

4 See, for example, Colin Hoskins, Stuart McFadyen, and Adam Finn, Media Economics: Applying Economics to New and Traditional Media (Thousand Oaks, CA: Sage, 2004); Alan Albarran, The Media Economy (New York: Routledge, 2010); Gillian Doyle, Understanding Media Economics (2nd ed.; London: Sage, 2013).

${ }^{5}$ Doyle, Understanding Media Economics, 1.

${ }^{6}$ Robert M. Entman and Steven S. Wildman, "Reconciling Economic and Non-economic Perspectives on Media Policy: Transcending the 'Marketplace of Ideas,'" Journal of Communication 42, no. 1(1992): 5, 7.

7 Steven Wildman, "Paradigms and Economic Frameworks in Modern Economics and Media Economics," in Handbook of Media Management and Economics, ed. Alan Albarran, Sylvia M. Chan-Olmsted, and Michael O. Wirth (Mahwah, NJ: Lawrence Erlbaum Associates, 2006), 68.

8 Pieter Ballon, "Old and New Issues in Media Economics," in The Palgrave Handbook of European Media Policy, ed. Karen Donders, Caroline Pauwels, and Jan Loisen (Basingstoke: Palgrave, 2014), 76.

9 Janet Wasko, Graham Murdock, and Helena Sousa, "Introduction: The Political Economy of Communication: Core Concerns and Issues," in The Handbook of Political Economy of Communications, ed. Janet Wasko, Graham Murdock, and Helena Sousa (Malden, MA: Wiley-Blackwell, 2011), 4.

${ }^{10}$ Joseph E. Stiglitz, Freefall: America, Free Markets, and the Sinking of the World Economy (New York: W. W. Norton, 2010), 238.

${ }^{11}$ John Quiggin, Zombie Economics: How Dead Ideas Still Walk among Us (Princeton, NJ: Princeton University Press, 2010), 211.

12 Robert G. Picard, "Economic Approaches to Media Policy," in The Handbook of Global Media and Communication Policy, ed. R. Mansell and M. Raboy (Malden, MA: WileyBlackwell, 2011), 355-63.

13 Vincent Mosco, The Political Economy of Communication (2nd ed.; London: Sage, 2009).

${ }^{14}$ Dwayne Winseck, "The Political Economies of Media and the Transformation of the Global Media Industries," in The Political Economies of Media: The Transformation of the Global Media Industries, ed. Dwayne Winseck and Dal Yong Jin (London: Bloomsbury, 2011), 3-48.

15 Eileen R. Meehan and Janet Wasko, "In Defence of a Political Economy of the Media," Javnost-The Public 20, no. 1 (2013): 39-54.

${ }_{16}$ Michel Foucault, "Governmentality," in The Foucault Effect: Studies in Governmentality, ed. Graham Burchell, Colin Gordon, and Peter Miller (London: Harvester Wheatsheaf, 1991), 87-104.

${ }^{17}$ Geoffrey Hodgson, "Meanings of Methodological Individualism," Journal of Economic Methodology 14, no. 2 (2007): 213.

18 William H. Melody, "Information: An Emerging Dimension of Institutional Analysis," Journal of Economic Issues 21, no. 3 (1987): 1313-39.

${ }^{19}$ Douglass C. North, "Economic Performance through Time," American Economic Review 84, no. 3 (1994): 359-68.

20 Oliver E. Williamson, Markets and Hierarchies (New York: Free Press, 1975), 1. 
${ }^{21}$ Erik G. Furubotn, and Rudolf Richter, Institutions and Economic Theory: The Contribution of the New Institutional Economics (Ann Arbor: University of Michigan Press, 2005), 556.

22 Richard Caves, Creative Industries: Contracts between Art and Commerce (Cambridge, MA: Harvard University Press, 2000).

${ }^{23}$ Ronald Coase, "The Nature of the Firm," Economica 4, no. 16 (1937): 386-405.

${ }^{24}$ North, "Economic Performance through Time," 360.

25 Douglass C. North, Institutions, Institutional Change, and Economic Performance (Cambridge: Cambridge University Press, 1990), 3.

${ }^{26}$ Oliver E. Williamson, "The New Institutional Economics: Taking Stock, Looking Ahead," Journal of Economic Literature 38, no. 3 (2000): 596-98.

27 Eric D. Beinhocker, The Origin of Wealth: Revolution, Complexity, and the Radical Remaking of Economics (London: Random House, 2006).

28 See, for example, George Catephores, "The Imperious Austrian: Schumpeter as Bourgeois Marxist," New Left Review 205, no. 1 (1994): 3-15.

${ }^{29}$ Wikipedia, s.v. "Creative destruction", accessed October 3, 2014.

30 Joseph Schumpeter, Capitalism, Socialism, and Democracy (New York: Harper Books, 1942).

${ }^{31}$ Major figures include Charles Edquist, Systems of Innovation: Technologies, Institutions and Organisations (London: Pinter, 1997); Bengt-Ake Lundvall, "Innovation as an Interactive Process: From User-Producer Interaction to the National System of Innovation," in Technical Change and Economic Theory, ed. Giovanni Dosi, Christopher Freeman, Richard Nelson, Gerald Silverberg, and Luc Soete (London: Pinter, 1988), 349-69; Christopher Freeman, Technology Policy and Economic Performance: Lessons from Japan (London: Pinter, 1987); Richard Nelson, National Innovation Systems: A Comparative Analysis (Oxford: Oxford University Press, 1993).

32 See, J. Stanley Metcalfe, Evolutionary Economics and Creative Destruction (London: Routledge, 1998).

${ }^{3}$ See, for example, Stuart Cunningham and Jon Silver, Screen Distribution and the New King Kongs of the Online World (New York: Palgrave Macmillan, 2013).

34 See, for example, James B. Moody and Bianca Nogrady, The Sixth Wave: How to Succeed in a Resource-Limited World (North Sydney: Random House/Vintage, 2010).

${ }^{35}$ Hoskins, McFadyen, and Finn, Media Economics, 297-99.

36 Mark Armstrong, "Public Service Broadcasting," Fiscal Studies 26, no. 3 (2005): 281-99.

37 Gavyn Davies, The BBC and Public Value (London: Social Market Foundation, 2004).

38 See, for example, Glasgow University Media Group, Bad News (London: Routledge and Kegan Paul, 1976); Philip Schlesinger, Putting "Reality" Together: BBC News (London: Constable, 1979).

39 Graham Murdock, "Communication in Common," International Journal of Communication 7 (2013): 154-72.

40 Richard Collins, "'Ises' and 'Oughts': Public Service Broadcasting in Europe," in The Television Studies Reader, ed. Robert C. Allen and Annette Hill (London: Routledge, 2004), 38.

41 Ibid.

42 Richard Caves, Creative Industries: Contracts between Art and Commerce (Cambridge, MA: Harvard University Press, 2000). 
43 "Getting the Best Out of the BBC for Licence Fee Payers," BBC Trust, accessed October 3, 2014.

44 Peter Preston, “The BBC Gets Its Woman, but Where Does Its Future Lie?," Guardian, August 31, 2014.

45 Christian Potschka, "Broadcasting and Market-Driven Politics in the UK and Germany: The Peacock Committee in Comparative Perspective," International Journal of Cultural Policy 19, no. 5 (2013): 595-609.

${ }^{46}$ John Benington and Mark H. Moore, "Public Value in Complex and Changing Times," in Public Value Theory and Practice, ed. John Benington and Mark H. Moore (Basingstoke: Palgrave, 2011), 1-30.

47 Davies, The BBC and Public Value.

48 Benedetta Brevini, Public Service Broadcasting Online: A Comparative Study of PSB 2.0 (Basingstoke: Palgrave, 2013), 76-77.

49 Ibid., 111.

50 Ibid., 114-15.

51 See, for example, David J. Lee, Kate Oakley, and Richard Naylor, "“The Public Gets What the Public Wants'? The Uses and Abuses of 'Public Value' in Contemporary British Cultural Policy," International Journal of Cultural Policy 17, no. 3 (2011): 289-300.

52 Stuart Cunningham, Hidden Innovation: Industry, Policy, and the Creative Sector (Lanham, MD: Lexington Books, 2014), 95.

53 Fiona Martin and Gregory F. Lowe, "The Value and Values of Public Service Media," in The Value of Public Service Media, ed. Gregory F. Lowe and Fiona Martin (Göteburg: Nordicom, 2014), 36.

\section{Bibliography}

Albarran, Alan. The Media Economy. New York: Routledge, 2010.

Armstrong, Mark. "Public Service Broadcasting." In Fiscal Studies 26, no. 3 (2005): 281-99.

Ballon, Pieter. "Old and New Issues in Media Economics." In The Palgrave Handbook of European Media Policy, edited by Karen Donders, Caroline Pauwels, and Jan Loisen, 70-95. Basingstoke: Palgrave, 2014.

BBC Trust. "Getting the Best Out of the BBC for Licence Fee Payers." Accessed October 3, 2014.

Beinhocker, Eric D. The Origin of Wealth: Revolution, Complexity, and the Radical Remaking of Economics. London: Random House, 2006.

Benington, John, and Mark H. Moore. "Public Value in Complex and Changing Times." In Public Value Theory and Practice, edited by J. Benington and Mark H. Moore, 1-30. Basingstoke: Palgrave, 2011.

Brevini, Benedetta. Public Service Broadcasting Online: A Comparative Study of PSB 2.0. Basingstoke: Palgrave, 2013. 
Catephores, George. "The Imperious Austrian: Schumpeter as Bourgeois Marxist." New Left Review 205 (1994): 3-30.

Caves, Richard. Creative Industries: Contracts Between Art and Commerce. Cambridge, MA: Harvard University Press, 2000.

Coase, Ronald. “The Nature of the Firm.” Economica 4, no. 16 (1937): 386-405.

Collins, Richard. "'Ises' and 'Oughts': Public Service Broadcasting in Europe.” In The Television Studies Reader, edited by Robert C. Allen and Annette Hill, 33-51. London: Routledge, 2004.

Cunningham, Stuart. Hidden Innovation: Industry, Policy, and the Creative Sector. St Lucia: University of Queensland Press, 2013.

Cunningham, Stuart, and Jon Silver, Screen Distribution and the New King Kongs of the Online World. New York: Palgrave Macmillan, 2013.

Davies, Gavyn. The BBC and Public Value, London: Social Market Foundation, 2004.

Doyle, Gillian. Understanding Media Economics. 2nd ed. London: Sage, 2013.

Earl, Peter E., and Ti-Ching Peng. "Brands of Economics and the Trojan Horse of Pluralism." Review of Political Economy 24, no. 3 (2012): 451-67.

Edquist, Charles. Systems of Innovation: Technologies, Institutions, and Organisations. London: Pinter, 1997.

Entman, Robert M., and Steven S. Wildman. "Reconciling Economic and Non-economic Perspectives on Media Policy: Transcending the 'Marketplace of Ideas." Journal of Communication 42, no. 1 (1992): 5-19.

Foucault, Michel. "Governmentality." In The Foucault Effect: Studies in Governmentality, edited by Graham Burchell, Colin Gordon, and Peter Miller, 87-104. London: Harvester Wheatsheaf, 1991.

Freeman, Christopher. Technology Policy and Economic Performance: Lessons from Japan. London: Pinter, 1987.

Furubotn, Erik G., and Rudolf Richter. Institutions and Economic Theory: The Contribution of the New Institutional Economics. Ann Arbor: University of Michigan Press, 2005.

Glasgow University Media Group. Bad News. London: Routledge and Kegan Paul, 1976.

Hobsbawm, Eric J. Industry and Empire. Harmondsworth: Penguin, 1979.

Hodgson, Geoffrey. "Meanings of Methodological Individualism." Journal of Economic Methodology 14, no. 2 (2007): 211-26. 
Hoskins, Colin, Stuart McFadyen, and Adam Finn. Media Economics: Applying Economics to New and Traditional Media. Thousand Oaks, CA: Sage, 2004.

Lee, David J., Kate Oakley, and Richard Naylor. "'The Public Gets What the Public Wants'? The Uses and Abuses of 'Public Value' in Contemporary British Cultural Policy." International Journal of Cultural Policy 17, no. 3 (2011): 289-300.

Lundvall, Bengt-Åke. "Innovation as an Interactive Process: From User-Producer Interaction to the National System of Innovation." In Technical Change and Economic Theory, edited by Giovanni Dosi, Christopher Freeman, Richard Nelson, Gerald Silverberg, and Luc Soete, 349-69. London: Pinter, 1988.

Martin, Fiona, and Gregory F. Lowe. "The Value and Values of Public Service Media." In The Value of Public Service Media, edited by Gregory F. Lowe and Fiona Martin, 19-40. Göteburg: Nordicom, 2014.

Meehan, Eileen R., and Janet Wasko. "In Defence of a Political Economy of the Media." JavnostThe Public 20, no. 1 (2013): 39-53.

Melody, William H. "Information: An Emerging Dimension of Institutional Analysis." Journal of Economic Issues 21, no. 3 (1987): 1313-39.

Metcalfe, J. Stanley. Evolutionary Economics and Creative Destruction. London: Routledge, 1998.

Moody, James B., and Bianca Nogrady. The Sixth Wave: How to Succeed in a Resource-Limited World. North Sydney: Random House/Vintage, 2010.

Mosco, Vincent. The Political Economy of Communication. 2nd ed. London: Sage, 2009.

Murdock, Graham. "Communication in Commons." International Journal of Communication 7 (2013): 154-72.

Nelson, Richard. National Innovation Systems: A Comparative Analysis. Oxford: Oxford University Press, 1993.

North, Douglass C. “Economic Performance through Time.” American Economic Review 84, no.3 (1994): 359-68.

North, Douglass C. Institutions, Institutional Change, and Economic Performance. Cambridge: Cambridge University Press, 1990.

Picard, Robert G. "Economic Approaches to Media Policy." In The Handbook of Global Media and Communication Policy, edited by Robin Mansell and Marc Raboy, 355-63. Malden, MA: Wiley-Blackwell, 2011.

Potschka, Christian. "Broadcasting and Market-Driven Politics in the UK and Germany: The Peacock Committee in Comparative Perspective," International Journal of Cultural Policy 19, no. 5 (2013): 595-609. 
Preston, Peter. “The BBC Gets Its Woman, But Where Does Its Future Lie?" Guardian, August 31, 2014.

Quiggin, John. Zombie Economics: How Dead Ideas Still Walk among Us. Princeton, NJ: Princeton University Press, 2010.

Schlesinger, Phllip. Putting 'Reality' Together: BBC News. London: Constable, 1979.

Schumpeter, Joseph. Capitalism, Socialism, and Democracy. New York: Harper Books, 1942.

Stiglitz, Joseph E. Freefall: America, Free Markets, and the Sinking of the World Economy. New York: W. W. Norton, 2010.

Wasko, Janet, Graham Murdock, and Helena Sousa. "Introduction: The Political Economy of Communication: Core Concerns and Issues." In The Handbook of Political Economy of Communications, edited by Janet Wasko, Graham Murdock, and Helena Sousa, 1-10. Malden, MA: Wiley-Blackwell, 2011.

Wildman, Steven. "Paradigms and Economic Frameworks in Modern Economics and Media Economics." In Handbook of Media Management and Economics, edited by Alan Albarran, Sylvia M. Chan-Olmsted, and Michael O. Wirth, 67-90. Mahwah, NJ: Lawrence Erlbaum Associates, 2006.

Williamson, Oliver E. Markets and Hierarchies. New York: Free Press, 1975.

- - . “The New Institutional Economics: Taking Stock, Looking Ahead." Journal of Economic Literature 38 (2000): 595-613.

Winseck, Dwayne. "The Political Economies of Media and the Transformation of the Global Media Industries." In The Political Economies of Media: The Transformation of the Global Media Industries, edited by Dwayne Winseck and Dal Yong Jin, 3-48. London: Bloomsbury, 2011.

\section{(cc) BY-NC-ND}

Copyright (C) 2015 (Stuart Cunningham and Terry Flew). Media Industries is an open-access, peer-reviewed, online academic journal. As such, we aim to participate in the open exchange of information. This work is licensed under a Creative Commons Attribution Noncommercial No Derivatives (by-nc-nd) License. Under this license, this work is available for sharing and noncommercial distribution provided the appropriate attribution is given. 